\title{
Student Political Participation and the Future of Democracy in Indonesia
}

\author{
Zainul Djumadin' \\ DOI: 10.35445/alishlah.v13i3.1438
}

\begin{abstract}
Article Info
Abstract

Keywords: Political Participation; Students;

Democracy; General

Election;

White Group (Golput)

Political participation entails discussing the activities of individuals or groups of individuals in political life. Each citizen is required to participate in formulating and implementing all state political policies. Students are intelligent individuals who are a country's greatest asset. Students' political participation will feel more meaningful because they are recognized as idealistic and uncontaminated by various destructive ideas. This study seeks to ascertain student political participation and the future of Indonesian democracy. This study analyzes research data using a qualitative approach combined with descriptive methods. Students' political participation in democracy can be seen through their participation in democratic elections as novice voters; their participation in elections provides political sensitivity and stimulates students to become more actively involved in politics; their involvement in politics enables them to develop social character, allowing them to be self-sufficient in determining their desires and resistant to persuasion. Additionally, there is a need for political education for students in this study. It is not easy to swallow false information that specific individuals do not truly create due to Indonesia's political lack of experience and knowledge.
\end{abstract}

Kata kunci:

Partisipasi Politik;

Mahasiswa;

Demokrasi;

Pemilihan Umum;

Golongan Putih (Golput)

\begin{abstract}
Abstrak
Partisipasi politik artinya kita akan membicarakan tentang kegiatan atau kegiatan masyarakat sebagai warga negara dalam kehidupan politik. Setiap warga negara untuk berpartisipasi dalam proses pembuatan dan perumusan semua kebijakan negara. Mahasiswa adalah individu cerdas yang merupakan aset penting bagi suatu negara. Partisipasi politik mahasiswa akan terasa lebih bermakna karena dianggap dan tahu bahwa dirinya juga idealis dan belum terkontaminasi oleh berbagai pemikiran yang destruktif. Oleh karena itu, penelitian ini bertujuan untuk mengetahui partisipasi politik mahasiswa dan masa depan demokrasi di Indonesia. Penelitian ini menggunakan metode deskriptif dalam menganalisis data penelitian. Partisipasi politik mahasiswa dalam berdemokrasi dapat dilihat dengan keikutsertaannya dalam pemilu yang demokratis sebagai pemilih, dengan keikutsertaan mahasiswa dalam pemilu akan memberikan dukungan dan rangsangan politik kepada mahasiswa untuk lebih aktif terlibat dalam politik, dengan mereka lebih aktif terlibat dalam politik. akan mampu mengembangkan sosial sehingga mandiri dalam menentukan keinginannya dan tidak mudah terpengaruh oleh karakter yang digunakan dan ajakan dari pihak tertentu. Hasil penelitian menunjukkan perlu adanya pendidikan politik bagi mahasiswa. Tidak mudah mengetahui informasi
\end{abstract}

\footnotetext{
${ }^{1}$ Universitas Nasional, Jakarta, Indonesia
}

Email: zainul.djumadin.unas@gmail.com

Vol.13 (3) December, 2021

Received: November 17, 2021; Received in revised form: November 30, 2021; Accepted: December 25, 2021; Available online: December 30, 2021. This is an open access article under a Creative Commons Attribution-NonCommercial-ShareAlike 4.0 International License. 
palsu yang tidak benar-benar dibuat oleh individu tertentu karena minimnya pengalaman dan pengetahuan di bidang politik di Indonesia.

\section{INTRODUCTION}

Indonesia is a democratic country in which the highest power is in the hands of the people; in the end, it is the people who have the right to choose who will become president, choosing the leader of the state or elections are part of political participation (Irawan, 2016). Political participation is an essential aspect in the order of a democratic state, which is also a criterion for the presence of political modernization, generally, in traditional societies where the nature of political leadership is dominant, the determination of which is from the ruling elite, then the involvement of citizens will affect the life of the nation which is relatively tiny and affects decision making (Subekti, 2014). Then Wardhani (2018) explains that political participation has something to do with democracy, which influences the legitimacy of society throughout a government. In an election, for example, political participation affects the legitimacy of the community for the candidate pair to be elected.

Miriam Budiardjo (1982), in his writings on participation and political parties, defines political participation in general as the activity of a person or group of people to actively participate in political life, namely by electing state leaders and, directly or indirectly, influencing government policies (public policy). Then what kind of activity can be called political participation. This concerns the conceptualization of political participation. Conceptualization is an effort to compile signs as criteria to determine whether a fact is included or not included in the concept. According to Samuel $\mathrm{P}$ Hungtinton \& Joan Nelson (2013), political participation is part of political attention that arises not because of coercion or coercive rules from the government or state. Still, political engagement grows in individuals because someone is aware of their rights and obligations as citizens. After all, participation is pseudo-perishable and easy to change. Eternal participation is participation that grows on self-awareness because they feel that they are part of the country's life and are required to participate in thinking about and advancing the life of their country (Neolaka, 2019).

Furthermore, Ramlan Surbakti (1992) gives signs or limitations regarding political participation as, first, political participation, which is intended to be in the form of external activities or behaviour of ordinary citizens that can be observed, not internal behaviour in the form of attitudes and orientations. Because individual perspectives and directions are not always manifested in their behaviour. Second, these activities influence the government as the maker and implementer of political decisions. Third, successful and effective activities fail to influence the government. Fourth, the actions of controlling the government both directly and without intermediaries and affecting the government by using intermediaries- for example, by using pressure groups that are considered capable of convincing the government. Fifth, activities to influence the government are carried out through reasonable (conventional) and non-violent procedures, such as voting in elections, submitting petitions, making face-to-face contact, writing letters, and non-conventional and violent activities such as demonstrations of defiance strikes. etc

Political participation in a democratic country is an indicator of the implementation of the highest legitimate state power by the people (people's sovereignty), which is manifested by their involvement in the democratic party (election) (Irma, 2021). The higher the level of political participation indicates that the people follow and understand and involve themselves in-state activities. On the other hand, a low level of political participation generally shows that the people lack appreciation or interest in state issues or activities (Haryono, 2019). The low level of people's political participation is reflected in the attitude of the white group in elections. Therefore, public political participation in general elections is also fundamental because low or high participation is an important signal and indicator of the course of the democratization process and the embodiment of popular sovereignty (Soebagio, 2008).

Research by Kurniasih (2020) explains that beginner voters in the general election are a new generation of voters with different traits and characters, backgrounds, experiences, and challenges 
from previous generations. Most of them come from among students, have good economic status, and generally live in urban or surrounding areas. This group is very touched by advances in information technology; they use advanced technology tools well, ranging from cellphones, laptops, tablets, and various other gadgets. They are also very fluent in using social media facilities and networks, such as Twitter, Facebook, linked in, and so on. They are very open to learning new things critically and independently (Ratnamulyani \& Maknai, 2018). The novice voter group faces formidable challenges, ranging from political changes and domestic problems that have no clear direction to resolve to the pressures of globalization, free trade, terrorism, international intervention, and so on. Differences in the nature and character, background, experience, and challenges of young voters in the general election need to be well understood, especially to prepare young voters who are intelligent, critical, and future-oriented (Setiawaty, 2014).

Then Lestari \& Arumsari (2018) explain that one of the few voters in the election who had a lot of influence on their democratic life was the novice voter, not only the number that had increased, the ability through the critical power of the novice voters could determine the outcome of the election. Beginner voters are usually 17 to 21 years old. Still, they belong to other categories where they used their right to vote for the first time, namely first-semester students and other youth groups wherein the previous election they were not quite 17 years old (Liando, 2017).

As previously mentioned, one of the categories said to be the younger generation is students. Therefore, students are part of the younger generation who should instil political awareness early. At the same time, students as a generation can be said to be the backbone of the country because they are the ones who will continue the future of the nation. Student participation arises because of a strong urge to the political environment. Their political insight is formed from their knowledge and background. In the school environment, students' participation in politics is usually centred on issues that develop in cyberspace, making students' political awareness vary greatly with national political issues that grow on the broader community.

\section{METHODS}

In order to provide the reader with a comprehensive overview of the research that has been done on a specific topic, this research used the method of literature study, which aims to provide a rationale for research that has already been done or to provide new ideas for further research (Denney \& Tewksbury, 2013). Students' political participation in Indonesia was documented in order to ensure that the findings were comparable and representative. The information used in this study was gleaned from studies published in peer-reviewed national journals online. The researcher used search engines like ProQuest, PubMed, Research Gate, SagePub, and Scholar to find articles published on the internet. Students' political participation, the role of the family in educational politics, and Indonesian democracy were some of the search terms used. The selection criteria were initially applied broadly. You can use any part of the article as a search term. Only article titles, abstracts, and keywords were thoroughly screened due to a large number of hits. It's important to note that Indonesia's educational policy, suitability of keywords for writing, and relevance of findings are all considered when selecting journals for collection. Snowballing was also used to find more relevant studies by going through the reference lists of the publications that had been selected. Only three scientific journals and eight community service publications made the final cut. Research by Petticrew and Roberts (2006) has been used to examine narrative synthesis in narratives. The steps outlined in this paper were designed to help students across Indonesia better understand their political participation in various contexts.

\section{FINDINGS AND DISCUSSION}

\section{Student Political Participation as Beginner Voters}

First-time voters are citizens who, based on statutory provisions, have met the requirements as voters, who for the first time use their right to vote in a general election (national election or 
regional election) (Sutisna, 2017). Based on this definition, the range of citizens who can become first-time voters can be wide and varied. In addition to its potential, it consists of students and students who are in the age range between 17-22 years (calculated based on the implementation of the 5 -year election), also includes young people who are in that age range; citizens who have been/have been married even though they have not reached the age of 17 years, and retired TNI/Polri. In this study, beginner voters are limited to high school/MA/vocational high school students who, for the first time, use their right to vote in an election, both national and regional elections (Fajar, 2014; Mutia et al., 2014).

Articles 19 and 20 of Law No. 10 of 2008 state that "novice voters" are Indonesian citizens who are already 17 years old or older on election day or voting day, or who are married or have been married at the time of the election or voting. Who is eligible to vote, and who was previously excluded because of the Election Law's provisions. The following characteristics are common among high school seniors who are first-time voters: (1) between the ages of 17 and 19 years; (2) the level of political literacy (political literacy) is still relatively low; and (3) political orientation and preferences are still very strongly influenced by people who are the reference for knowledge, attitudes, and behaviour like teachers and parents; and partly by peer groups (peer groups, playgroups).

First-time political voters fall into the broad category of those who exercise their franchise for the first time. A new voter's political views are always fluid and subject to shifts based on the current environment and the various influences. Every general election is a good opportunity for a candidate to secure a strategic position, and novice voters are unquestionably an important part of that process (Rompas, 2020). Anyone who manages to get their attention will reap the rewards. In the absence of this group's support, the election vote targets will be severely damaged.

The nature of politics in a democratic system is complicated, as Stoker (2006) argues. In the absence of corruption and collusion, it is difficult to bring disparate interests together, manage negotiations, and articulate them as a shared decision. Citizens are also called political amateurs because of the complexity of the existing systems and institutions and because they participate in politics on a piecemeal basis with a lower level of capacity than political professionals or political actors like lobbyists, activists, cadres of political parties, and council members (Karim, 2001). As a group, novice voters have a lower capacity and competence than other political amateurs. Amateurs own the vast majority of sovereignty.

The forms of participation carried out by novice voters in the context of the general election are campaigns, which are activities carried out to influence and attract sympathy and get as many votes as possible from the voters to choose specific candidates and win them. The campaign is an essential part of general election activities. Most of the Beginner Voters already know the purpose of the movement itself, which is to provide election information and explain the vision and mission to attract sympathy for voting. The opinion of the novice voters that campaigning is an activity that takes up time and clashes with their daily activities has resulted in the novice voters being reluctant to participate in campaign activities. There are also novice voters who think that they do not participate in the campaign because they do not like the hustle and bustle of an open campaign atmosphere. Some novice voters' opinions illustrate the lack of interest from novice voters to participate in campaign activities, apart from those who are not accustomed to participating in campaign activities because they clash with school activities (Wardhani, 2017; Yang, 2020).

Factors supporting the political participation of novice voters in the general election are Milbrath (1981) giving four reasons for the variation of a person's political involvement. First, regarding the acceptance of political incentives. Milbrath said that one's openness and sensitivity to political stimuli through personal contacts, organizations, and the mass media would affect one's participation in political activities. His transparency and sensitivity to receive political incentives through the mass media will encourage someone to be actively involved in politics. By actively following political developments through the mass media, a person will have enough actual references to respond and ultimately as an ingredient in his political participation. However, 
responding to political stimuli is undoubtedly influenced by a person's knowledge, attitudes, values, experiences, and personality. Beginner voters are encouraged to participate in the General Election because there is stimulation from the mass media or electronics.

The second reason, according to Milbrath, relates to a person's social characteristics. Economic status, ethnic character, age, gender, and religion are social characteristics that influence political participation. Novice voters have different social, personal characteristics. Still, from these differences, novice voters are pretty many people who care and are aware of their political rights as a society. According to the invitation they received, they want to participate in the election by coming to the polling station where they live. Third, it concerns the political system and the party system in which individuals live. Someone who lives in a democratic country tends to participate in politics because political parties tend to seek support from the masses and fight for the interests of the groups. The novice voters have different social, personal characteristics. Still, from the differences, the novice voters are quite a lot concerned and aware of their political rights, their role as a society. Meanwhile, Milbrath's fourth reason is in the form of regional differences. This regional difference is an environmental aspect that influences the individual character and behaviour differences, thus encouraging differences in one's political behaviour and political participation. Almost every area is safe and conducive to participating in elections, including novice voters. Novice voters participate in elections based on their own will, no direction from others, no tricky thing.

\section{Student Political Participation and the Future of Indonesian Democracy}

Aristotle said that man is a Zoon Politicon or a political animal. This means that humans cannot live alone; they must coexist to fulfil their needs and desires as humans. This interdependence gives birth to the principle of equality of life. The common goal cannot be formed by 1 or 2 people but by many people so that the goal is more decisive. If we look at the political changes that have taken place in Indonesia, which have taken place dramatically, it has put this nation in a dilemmatic and challenging position and constellation. This kind of condition in education shows that there has been a very long engineering process. The theory that proves the existence of a very close relationship between politics, economy, and education does not appear among the nation's children.

Student political participation becomes very important and strategic because students and youth as agents of change must oversee the democratic transition process towards a more substantive one. To supervise the process, students and children can participate either as organizers, participants, or supervisors of the political implementation process in Indonesia. Youth must be able to appear as agents of guarding morals and political ethics in the democratic process, meaning that participation in politics must be able to run according to applicable legal rules, political attitudes and behavior that is carried out must uphold political ethics and manners so as not to apply political practices that dirty, justifies all means and uses violent means or political thuggery. Youth must appear as guardians of democracy, respecting the rights and obligations of others, respecting differences in choices, and not being trapped in political pragmatism (Wringe, 2012; Sutrisman, 2019; Yi \& Dan, 2020).

To take into account the role and political participation of youth, every youth should have:

1. Strong commitment, determination, and consistency in fighting for and realizing ideals for the benefit of the community, nation, and state. Not trapped in ambiguous attitudes, not having the courage and commitment to idealism or ideology, principles of struggle and ideals. Commitment concerns the contract of conscience that must be firmly held to realize the plans through work. If this can be controlled, it will undoubtedly be a young man who is not labeled as a "jumping flea".

2. Integrity, namely upholding moral and ethical values, its vibration can be felt and seen from polite attitudes and behaviour in politics. Many people mistakenly think that politics is cruel, that politics justifies any means, as long as the goal is achieved, even if it is justified. In a very 
short and pragmatic count, maybe yes. But actually, it is pseudo. Therefore, self-integrity is a long-term investment that should be maintained as wisdom.

3. Competence, namely the ability or quality of human resources, is the primary capital that must be developed continuously. Understanding other people, identifying and formulating problems, and finding solutions is a learning and maturation process that must be constantly developed. The phrase long-life education is essential to be implanted as an orientation to increase competence.

4. Constituencies, including support and networks from as many people as possible. Maintaining good relationships and building networks that have been built is a job that should not be neglected in doing business. Because after all, trust and efforts to gain power in elegant ways such as influencing other parties so that the affected party does not feel humiliated and or happy to provide support will provide a positive value.

Today, many young people (students) express a unique style of political participation. Some are through social media, written criticism, action on the streets, or going directly into the world of politics. However, it is undeniable that there are still many students who are still apathetic towards the state. Students are very synonymous with social media. The role of the media is used to exchange information, whether it is private, public, or even untrue news. Fake news (hoax) is considered very effective in influencing the community. Hoax news helps build public opinion that the candidate is doing is valid. Hoaxes are aimed at people with low education and students. The students are considered very effective in driving sentiment. Moreover, for those active on social media, the news will be straightforward to spread to fellow social media users, especially to close friends of social media users.

Students who are still minimal with experience in participating in politics, of course, are elementary to be used as political tools to gain an advantage on one side. The thing that must be considered is those in an environment with high numbers of the White Group or known as GolPut. They will be easily influenced to become their group (Mirshak, 2020). Even more dangerous, those who are easily led to choose one candidate who is seen as having minimal experience and less qualified as people's representatives. Currently, the central and regional governments are very aggressively conducting political socialization to reduce the number of GolPut. This is due to the large number of abstentions in Indonesia which reached $29.8 \%$ in 2014. In a democratic country, the role of the community in providing demands and support is essential for the smooth running of a policy that will be realized.

Many people think that GolPut is an option, but that is a wrong perception. Moreover, it is wrong to believe that all candidates are the same. Currently, many leaders can manage their area well. Even if we choose qualified executive and legislative candidates, creative ideas will always emerge from them to develop their region and country. Students are particularly vulnerable to the GolPut score. Those who are already disappointed with their leaders make them reluctant to participate in the election process. Many of them are only enthusiastic about criticizing the government through social media. Many of them use social media only to insult candidates without contributing good ideas for this country. One of the government's efforts to suppress the GolPut number is running a Political Education program. With political education, students will have political knowledge to generate political participation at a certain level. They will also indirectly be able to influence their friends to participate in democracy (Seidel et al., 2020; Vakil, 2020).

The importance of political education for students helps increase community participation, especially students. In this case, they are not actively participating in elections but can provide demands and support to the government to birth policies right on target (Ulfatin et al., 2020). With the implementation of political education, students will understand the rights and obligations of citizens. Political education is compelling for students to understand the values and the phenomenon of politics in this country. In addition to helping suppress the GolPut number, political education 
can shape the character of the young generation who are intact, skilled, and aware of their role as citizens.

To prevent students from falling asleep in a hedonistic world. The government must be able to take advantage of existing institutions to run political education programs. If this phenomenon continues, students will become apathetic and don't care about the nation's fate.

\section{Family}

The family has an essential role in the education of children and the younger generation. The family becomes the complete control holder in determining the direction of the formation of children's character (Ballew et al., 2020). Concerning politics, families must provide an understanding of politics to their children. Starting from the minor thing, namely introducing government apparatus to the importance of the community in participating in providing support and demands to the government. Parents should often share past experiences in politics so that children are more convinced that their role as citizens is very much needed in politics. In addition, parents must often open communication with children to teach children about good communication with the government later. Children will no longer be awkward to participate in active politics.

\section{Educational Institution}

The choice of place to study becomes the primary determinant in determining the quality of learning outcomes for students and students. Usually, parents will direct them to schools that have good accreditation. In addition, parents also see the achievements of schools and universities that will be entered later. The environment within the school or university is also a significant concern for parents. Good quality education will help children to understand the lessons they will receive. Educational institutions also have a considerable role in shaping the character of the nation's children. Educational institutions directly indoctrinate and force students to obey and obey the rules that have been set (Winter et al., 2020; Abowits \& Mamlok, 2020). It always contains material for Pancasila and citizenship education at school or university. In this lesson, we describe in general the state, citizens, and politics in Indonesia. In addition to lessons, educators must play their role in various lines; both the relationship between educators and their students to the formation of the personal character of educators must be considered a helpful pilot event in the formation of students' personalities.

\section{Political parties}

According to Sigmund Neumann, political parties are organizations of political activists who seek to control government power and win popular support through competition with a group or other groups who have different views. Political parties also have an essential role in increasing political participation and understanding citizens. One of the functions of political parties is political education (Saputro, 2021; Widodo, 2021). Each party is given a budget to carry out this function. Political parties must be able to mobilize people to participate in politics. Political parties must frequently publish their flagship programs and in various media and journals. Often political parties provide training to the community or members that will raise a sense of community care for the state.

\section{Mass Media and Communication}

In this sophisticated era of globalization, it is straightforward to convey various information. The government must be able to use the media to provide understanding to the public. With frequent opinions in print and electronic media (McNair, 2017; Ziemes et al., 2020). With content as creative as possible in performance, the public will indirectly absorb the information obtained in the mass media (Stieglitz \& Dang-Xuan, 2013). Apart from that, the communication media that are currently developing are considered very effective for spreading various writings or short videos, especially among the generation of students who are very active in using communication media to apply different kinds of content, both through groups and personally (Martin, 2014). In addition, with the mass media, the government can control various information spread in multiple media. If fake news 
is distributed, the government will quickly clarify the statement so that fake news will not be consumed.

\section{CONCLUSION}

Students play a vital role in the development of democracy in Indonesia. Student political participation is a series of activities involving students' participation, both directly and indirectly, aiming to influence government policies concerning the public interest. One form of student political participation is in general elections. It is hoped that the participation of students as beginners in the general election can make future learning for students more concerned in the affairs of the nation and state. Students who are also the millennial generation are very taken into account in politics. They are very vulnerable to being controlled by irresponsible political elites. Millennials can also easily swallow Hoax information that specific individuals deliberately create. This is because Millennials still lack experience and knowledge in Indonesian politics. Therefore, the government must often provide understanding through political education, which is currently still effective to run. It is hoped that political education can be implemented with different innovations. This innovation is expected to suggest young people be involved in and sensitive to the phenomena that exist in Indonesia. In addition, political education can motivate all citizens to become political participate at the top level.

\section{REFERENCES}

Abowitz, K. K., \& Mamlok, D. (2020). \# NeverAgainMSD Student Activism: Lessons for Agonist Political Education in an Age of Democratic Crisis. Educational Theory, 7o(6), 731-748.

Ballew, M. T., Pearson, A. R., Goldberg, M. H., Rosenthal, S. A., \& Leiserowitz, A. (2020). Does socioeconomic status moderate the political divide on climate change? The roles of education, income, and individualism. Global Environmental Change, 6o, 102024.

Budiardjo, M. (1982). Partisipasi Dan Partai Politik Sebuah Bunga Rampai. Jakarta: Gramedia.

Fajar, W. N. (2014). Pelaksanaan Pendidikan Politik di Sekolah dalam Meningkatkan Kesadaran Politik Siswa. Khazanah Pendidikan, 6(2).

Haryono, D. (2019). Strategi KPU dalam meningkatkan partisipasi pemilih pada pemilihan Walikota dan Wakil Walikota Samarinda tahun 2015. Jurnal Administrative Reform, 6(2), 6773 .

Huntington, S. P., \& Nelson, J. M. (2013). No Easy Choice. Harvard University Press.

Irawan, B. B. (2016). Perkembangan Demokrasi di Negara Indonesia. Jurnal Ilmiah Hukum dan Dinamika Masyarakat, 5(1).

Irma, I. (2021). Rendahnya Partisipasi Politik Pemula Pada Pemilihan Umum. Jurnal Mahasiswa Karakter Bangsa, 1(1), 110-113.

Karim, L. (2001). Politics of the Poor-NGOs and Grass-Roots Political Mobilization in Bangladesh. PoLAR, 24, 92.

Kurniasih, D. (2020). Pendidikan Politik Pemilih Muda Dalam Pemilihan Kepala Desa Serentak di Kabupaten Bandung 2019. Indonesian Community Service and Empowerment Journal (IComSE), 1(1), 16-21.

Lestari, E. Y., \& Arumsari, N. (2018). Partisipasi Politik Pemilih Pemula pada Pemilihan Walikota Semarang di Kota Semarang. Integralistik, 29(1), 10.

Liando, D. M. (2017). Pemilu Dan Partisipasi Politik Masyarakat (Studi Pada Pemilihan Anggota Legislatif Dan Pemilihan Presiden Dan Calon Wakil Presiden Di Kabupaten Minahasa Tahun 2014). Jurnal LPPM Bidang EkoSosBudKum, 3(2), 14-28.

Martin, J. A. (2014). Mobile media and political participation: Defining and developing an emerging field. Mobile media \& communication, 2(2), 173-195.

McNair, B. (2017). An introduction to political communication. Routledge.

Milbrath, L. W. (1981). Political Participation. In The handbook of political behavior (pp. 197-240). Springer, Boston, MA.

Mirshak, N. (2020). Education as resistance: Egyptian civil society and rethinking political education under authoritarian contexts. Critical Sociology, 46(6), 915-930.

Moleong, L.J. (2002). Metode Penelitian Kualitatif. Bandung: Remaja Rosdakarya. 
Mutia, R. A., Widayanti, W., \& Astuti, P. (2014). Peran Sekolah dalam Pendidikan Politik Bagi Siswa di Sekolah Menengah Atas Islam Hidayatullah Semarang. Journal of Politic and Government Studies, 4(1), 16-25.

Neolaka, I. A. (2019). Isu-Isu Kritis Pendidikan: Utama dan Tetap Penting Namun Terabaikan. Prenada Media.

Ratnamulyani, I. A., \& Maksudi, B. I. (2018). Peran Media Sosial Dalam Peningkatan Partisipasi Pemilih Pemula Dikalangan Pelajar Di Kabupaten Bogor. Sosiohumaniora, 2O(2), 154-161.

Rompas, I. R. (2020). Perilaku Pemilih Pemula Pada Pemilihan Umum Tahun 2019 Di Desa Bongkudai Selatan Kecamatan Mooat Kabupaten Bolaang Mongodow Timur. Jurnal Politico, 9(1).

Saputro, R. H. (2021). Pendidikan Politik Sebagai Amanat Undang-Undang. Journal Civics \& Social Studies, 5(1), 147-157.

Seidel, S., Bettinger, P., \& Budke, A. (2020). Representations and concepts of borders in digital strategy games and their potential for political education in geography teaching. Education Sciences, $10(1), 10$.

Setiawaty, D. (2014). Mendorong Partisipasi Pemilih Muda Melalui Pendidikan Politik Yang Programatik. Islamic Review: Jurnal Riset Dan Kajian Keislaman, 3(1), 117-146.

Soebagio, H. (2008). Implikasi Golongan Putih dalam Perspektif Pembangunan Demokrasi di Indonesia. Sumber, 21(8).

Stieglitz, S., \& Dang-Xuan, L. (2013). Social media and political communication: a social media analytics framework. Social network analysis and mining, 3(4), 1277-1291.

Stoker, G. (2006). Politics In Mass Democracies: Destined to Disappoint? Representation, 42(3), 181-194.

Subekti, T. (2014). "Partisipasi Politik Masyarakat dalam Pemilihan Umum (Studi Turn of Voter dalam Pemilihan Umum Kepala Daerah Kabupaten Magetan Tahun 2013)" (Doctoral dissertation, Brawijaya University).

Sugiyono, P. (2011). Metodologi Penelitian Kuantitatif Kualitatif Dan R\&D. Bandung: Alpabeta.

Surbakti, R. (1992). Memahami Ilmu Politik. Grasindo.

Sutisna, A. (2017). Peningkatan Literasi Politik Pemilih Pemula Melalui Pendekatan Pembelajaran Kontekstual. In Prosiding Seminar Nasional Pendidikan FKIP (Vol. 1, No. 2).

Sutrisman, D. (2019). Pendidikan Politik, Persepsi, Kepemimpinan, dan Mahasiswa. Guepedia.

Ulfatin, N., Mustiningsih, Sumarsono, R. B., \& Yunus, J. N. (2020). School-based management in marginal areas: Satisfying the political context and student needs. Management in Education, 0892020620959739.

Vakil, S. (2020). "I've Always Been Scared That Someday I'm Going to Sell Out": Exploring the relationship between Political Identity and Learning in Computer Science Education. Cognition and Instruction, 38(2), 87-115.

Wardhani, P. S. N. (2018). Partisipasi Politik Pemilih Pemula dalam Pemilihan Umum. Jupiis: Jurnal Pendidikan Ilmu-Ilmu Sosial, 1o(1), 57-62.

Widodo, H. (2021). Pendidikan Holistik Berbasis Budaya Sekolah. UAD PRESS.

Winter, L. A., Hanley, T., Bragg, J., Burrell, K., \& Lupton, R. (2020). 'Quiet activism'in schools: conceptualising the relationships between the personal, the political and the Political in education. Cambridge Journal of Education, 5O(3), 391-408.

Wringe, C. (2012). Democracy, Schooling and Political Education (RLE Edu K). Routledge.

Yang, F. (2020). Analysis on the Relationship Between the Media Literacy of Film \& Television and the Innovation of Ideological and Political Education of Contemporary College Students. Lifelong Education, 9(2), 41-44.

Yi, Y., \& Dan, W. (2020). The realization of ideological and political education in college English based on cultural confidence. Creative Education, 11(11), 2193.

Ziemes, J. F., Hahn-Laudenberg, K., \& Abs, H. J. (2020). The impact of schooling on trust in political institutions-Differences arising from students' immigration backgrounds. Learning, Culture and Social Interaction, 26, 100429. 
Al- Ishlah: Jurnal Pendidikan, December 2021, 13 (3), Pages 2399-2408

Zainul Djumadin

This page is intentionally left blank 